\title{
Secondary School Teachers' and Students' Attitudes Towards Formative Assessment and Corrective Feedback in English Language in Ibadan Metropolis
}

\author{
D.O. Fakeye, Ph.D \\ Department of Teacher Education, University of Ibadan,Ibadan; Fako4best@yahoo.com
}

Doi:10.5901/jesr.2016.v6n2p141

\section{Abstract}

\begin{abstract}
This study investigated teachers' and students' attitudes towards formative assessment and corrective feedback in English Language in Ibadan Metropolis. The study adopted a descriptive research design of survey type. The participants were 420 students and six teachers. The instruments used for data collection were: Attitudes of Teachers Towards Formative Assessment and Corrective Feedback in English Language Questionnaire ( $r=0.74)$. Attitudes of students towards formative assessment and corrective feedback in English Language questionnaire $(r=0.81)$. Data collected were analysed using frequency descriptive and t-test statistics. Findings revealed that teachers had positive attitudes to formative assessment and corrective feedback $((\bar{x}=35.00, S D=1.41)$. Students also had positive attitudes to formative assessment and corrective feedback in English language ( $(\bar{x}=3.71, S D=3.72)$. There was no significant difference between male and female teachers' attitudes to formative assessment and corrective feedback in English language. ( $t=1.63, p>$.05). There was no significant difference between male and female students'attitudes to formative assessment and corrective feedback $(t=3.41, p>.05)$. Based on the findings, it is recommended among others that formative assessment should be given more prominence in assessing students' learning outcome. In addition, English Language teachers should be exposed to seminars, conferences and workshops on how to deploy formative assessment and corrective feedback effectively in English classroom for better results.
\end{abstract}

Keywords: Formative assessment, corrective feedback, teachers' and students' attitudes, English language.

\section{Introduction}

The terms assessment and evaluation are often used interchangeably but in actual sense, they are two complementary phases of the same process. Assessment is the process of gathering evidence of what the child can do. Evaluation is the process that follows this collection of data, including analysis and reflection as well as decisions based on the data (ACELAC, 2014). Evaluation determines the value of programmes and acts as blueprint for judgment and improvement (Rossett and Sheldon, 2001). The ultimate goal of evaluation is the facilitation of learning. Other immediate purposes of evaluation are: placement, diagnosis, assessment and prediction (Fakeye, 2011).

Agbesanwa (2014) identified some assessment strategies that could be employed by the teacher in the English language tasks as paper and pencil test, quiz, portfolio, anecdotal record, interview, group work, performance task, question and answer (oral), observation and project. Each of these assessment strategies has its purpose in every language instruction depending on the domain in which it is used. However, most teachers do not use evaluation as a way of promoting learning . Evaluation should rather be used as a vehicle of teaching and learning.

In order to ameliorate the rate of students' failure in English language, scholars have suggested shifting focus from methods and strategies to assessment and feedback because quality of assessment could have great impact upon performance.

There are two broad types of assessments namely: formative and summative assessments. Black and William (1998) defined formative assessment as 'all those activities undertaken by teachers and/or by their students which provide information to be used as feedback to modify the teaching and learning activities on which they are engaged' (pg. 10). On the other hand, Evelyn and Joseph (2009) remarked that summative assessment helps determine to what extent the instructional and learning goals have been met.

Nesa (2014) noted that some teachers often complain about sacrificing time to assess during the lesson with the fear that they may not even finish the lesson. Despite its perceived shortcoming, formative assessment cannot be ruled out of any goal-oriented teaching and learning for its advantages. Formative assessment delivers information during the instructional process, before the summative assessment. Both the teacher and the students use formative assessment 
result to make decisions about what actions to promote further learning. It is an on-going dynamic process that involves far more than frequent testing and measurement of student learning is just one of its components (Stephen Chappuis and Jan Chappuis, 2007).Pinchok and Brandt (2009), among a number of experts, believed that the timeliness, flexibility and ongoing nature of formative assessment techniques were most helpful in informing instruction for teachers and closing achievement gaps for students and for preparing students for the short and long-term formative and summative benchmarks they must meet.

Formative assessment helps students to monitor their own progress as they get feedback from their peers and the teacher .Feedback is information a teacher or another speaker, including another learner, gives to learners on how well they are doing, either to help the learner improve specific points, or to help plan their learning.

Feedback can be immediate, during an activity, or delayed at the end of an activity or part of a learning programme and can take various forms. Providing feedback throughout lessons is important. It is something that will become second nature with just a little bit of practice. Feedback encourages students to work hard and indicate what they need to focus on when they are having difficulty (British Council, 2014).

Feedback is an assessment for learning context which occurs while there is still time to take action. It functions as a global positioning system, offering descriptive information about the work, product, or performance relative to the intended learning goals. Ellis, Loewen and Erlam (2006) described corrective feedback as the form of responses to utterances that contain error. The responses can consist of (a) an indication that an error has been committed (b) provision of the correct target language form, or (c) metalinguistic information about the nature of the error, or any combination of these.Formative assessment and corrective feedback facilitate students to achieve better not only in their summative assessment but also to help them to improve attendance and retention of learning.

Unfortunately, as important as formative assessment is, it is almost neglected as most teachers concentrate much on summative assessment.. Little researches have been conducted on Studies have shown that formative assessment is vital to academic success of learners but little has been done on teachers' and students' attitude towards formative assessment and corrective feedback especially in Ibadan Metropolis.

The attitudes of teachers and students may affect the use of formative evaluation. When the teacher is properly disposed to the use of formative evaluation and corrective feedback, he incorporates it in the lesson plan while the students would respond favourably to it..

\section{Statement of the Problem}

Studies have revealed that formative assessment and corrective feedback when effectively used could improve teaching and learning. In addition, the attitudes teachers and students carry to the classroom play a great role in determining success of learning. Most studies carried out on attitude towards formative assessment have been on different subjects especially mathematics and sciences without considering such for English language. Therefore, this study investigated teachers' and students' attitudes towards formative assessment and corrective feedback in English language teaching and leasrning in Ibadan Metropolis.

\section{Research Questions}

The study attempted to provide answers to the following questions:

1. What is the attitude of English teachers towards formative assessment and corrective feedback?

2. What is the attitude of students towards formative assessment and corrective feedback?

\section{Hypotheses}

1. There is no significant difference between male and female teachers' attitudes towards formative assessment and corrective feedback.

2. There is no significant difference between male and female students' attitudes towards formative assessment and corrective feedback.

\section{Significance of the Study}

The study established teachers' and students' attitude towards formative assessment and feedback in English language 
in Ibadan Metropolis. Findings from the study would provide empirical information on the attitude of teachers and students towards formative assessment and corrective feedback in English language.

\section{Methodology}

The study adopted descriptive research design of survey type. The design was considered appropriate because the intention was to gather information on the existing phenomenon and report the situation according to the observation of the respondents. The population of this study comprised all English language teachers and students in senior secondary schools in Ibadan North East Local Government Area of Oyo State. Six senior secondary schools were randomly selected from Ibadan North/East Local Government Area of Oyo State. From each school, a total number of seventy (70) students in senior secondary school two (SS II) were randomly selected to participate in the study. This makes a total of four hundred and twenty (420) participants. In addition, all SS II English language teachers from the six selected secondary schools participated in the study. In all, a total of six (6) English language teachers took part in the study. Total

The research instruments for data collection were two questionnaires titled: Questionnaire on Teachers' Attitudes Towards Formative Assessment and Corrective Feedback in English Language( $r=0.78)$ and Questionnaire on Students' Attitudes Towards Formative Assessment and Corrective Feedback in English Language ( $r=0.81)$. The principals in turn introduced the researcher to the heads of Englishdepartments in the schools who again handed over the researcher to the SS II English Language teachers who assisted in the administration of the questionnairesto the respondents. Data collected were analysed using descriptive statistics of frequency count, simple percentage, mean and standard deviation. To test for significant difference in the mean of male and female teachers' and students' attitudes to formative assessment and corrective feedback, t test statistics was used to test the hypothesis at 0.05 level of significance.

\section{Results}

\subsection{Research question 1: What is the attitude of teachers towards formative assessment and corrective feedback?}

Table 1: Teachers' Attitudes Towards Formative Assessment and Corrective Feedback

\begin{tabular}{|c|c|c|c|c|c|c|c|}
\hline S/N & Items & SA & A & D & SD & Mean & Std. D \\
\hline 1. & Formative assessment is good and adequate for teachers' use & $4(66.7)$ & 2(33.3) & - & - & 3.67 & .516 \\
\hline 2. & I rarely use formative assessment to evaluate my students' learning outcome & - & 1(16.7) & $2(33.3)$ & $3(50.0)$ & 1.67 & .816 \\
\hline 3. & Formative assessment is time consuming & - & 1(16.7) & $4(66.7)$ & $1(16.7)$ & 2.00 & .632 \\
\hline 4. & Formative assessment is interesting & $2(33.3)$ & $4(66.7)$ & - & - & 3.33 & .516 \\
\hline 5. & Formative assessment enhances learning & $2(33.3)$ & $4(66.7)$ & - & - & 3.33 & .516 \\
\hline 6. & Formative assessment leads to improvement in teaching performance & $2(33.3)$ & $4(66.7)$ & - & - & 3.33 & .516 \\
\hline 7. & I don't like asking questions while the lesson is going on & $3(50.0)$ & $3(50.0)$ & - & - & 1.50 & .548 \\
\hline 8. & Formative assessment makes my class boring & - & - & $4(66.7)$ & $2(33.3)$ & 1.67 & .516 \\
\hline 9. & Corrective feedback disrupts the lesson & - & - & $4(66.7)$ & 1(16.7) & 1.67 & .516 \\
\hline 10. & Corrective feedback is very tedious to give promptly and always & 1(16.7) & 1(16.7) & $3(50.0)$ & $3(50.0)$ & 2.33 & 1.033 \\
\hline 11. & I defer my corrective feedback till after the lesson & - & 1(16.7) & $4(66.7)$ & 1(16.7) & 2.00 & .632 \\
\hline 12. & I don't provide corrective feedback because of the number of students involved & - & - & $3(50.0)$ & $3(50.0)$ & 1.50 & .548 \\
\hline 13. & Corrective feedback demoralizes students. & - & - & $5(83.3)$ & 1(16.7) & 1.83 & .408 \\
\hline 14. & I don't like pointing out my students' mistakes in the class & - & - & $4(66.7)$ & 2(33.3) & 1.67 & .516 \\
\hline 15. & Corrective feedback helps me in knowing my students' mood. & $1(16.7)$ & $4(66.7)$ & - & $1(16.7)$ & 2.83 & .983 \\
\hline
\end{tabular}

From table 1, result of item 1 shows that 4 teachers representing $66.7 \%$ and 2 teachers representing $33.3 \%$ with mean of 3.67 and standard deviation of .52 agreed that formative assessment is good and adequate for teachers' use. 2 teachers representing $33.3 \%$ and 3 t3eachers representing $50.0 \%$ with mean of 1.67 and standard deviation of .82 disagreed that they rarely used formative assessment to evaluate students' learning outcome, this means they often use formative assessment to evaluate students' learning outcome. Item 3 shows that 4 teachers representing $66.7 \%$ and 1 teacher representing $16.7 \%$ with mean of 2.00 and standard deviation of .63 disagreed that formative assessment is time consuming, this means formative assessment does not consume their time. 2 teachers representing $33.3 \%$ and 4 teachers representing $66.7 \%$ with mean of 3.33 and standard deviation of .52 agreed that formative assessment is 
interesting and enhances learning. They further agreed that formative assessment leads to improvement in teaching performance (mean $=.516$ ). Item 8 shows that 4 teachers representing $66.7 \%$ and 2 teachers representing $33.3 \%$ with mean of 1.67 and standard deviation of .52 disagreed that formative assessment makes their classes boring; this implies that formative assessment does not make their classes boring.

The teachers' attitude on corrective feedback shows that it does not disrupt the lesson as 4 teachers representing $66.7 \%$ and 2 teachers representing $33.3 \%$ with mean of 1.67 and standard deviation of .52 disagreed that corrective feedback disrupts the lesson. Subsequently, 3 teachers representing $50.0 \%$ and 1 teacher representing $16.7 \%$ with mean of 2.33 and standard deviation of 1.03 disagreed that corrective feedback is very tedious to give promptly and always, this indicates that corrective feedback is easy to give promptly and always. Item 11 showsthat 4 teachers representing 66.7 and 1 teacher representing 16.7\% with mean of 2.00 and standard deviation of .63 disagreed that they defer their corrective feedback till after the lesson. This means they correct their students while the lesson is going on. Also, 5 teachers representing $83.3 \%$ and 1 teacher representing $16.7 \%$ with mean of 1.83 and standard deviation of .408 disagreed that corrective feedback demoralizes students; this indicates that corrective feedback does not cause students to lose confidence. This is followed by the level at which corrective feedback helps the teachers in knowing the mood of their students. 1 teacher representing $16.7 \%$ and 4 teachers representing $66.7 \%$ with mean of 2.83 and standard deviation of .98 agreed that corrective feedback helps them in knowing their students' mood. The overall weighted mean is 2.29. From this analysis, it can be concluded that English language teachers have positive attitudes to formative assessment and corrective feedback.

\subsection{Research question 2: What is the attitude of students towards formative assessment and corrective feedback?}

Table 2: Students' attitudes towards formative assessment and corrective feedback

\begin{tabular}{|c|c|c|c|c|c|c|c|}
\hline & Items & SA & $\mathrm{A}$ & D & SD & Mean & Std. D \\
\hline 1. & The use of formative assessment improves my performance. & $309(73.6)$ & $103(24.5)$ & $4(1.0)$ & $4(1.0)$ & 3.71 & .533 \\
\hline 2. & Formative assessment makes me to be actively involved in learning process. & $260(61.9)$ & $150(35.7)$ & $10(2.4)$ & - & 3.60 & 538 \\
\hline 3. & The use of formative assessment in English Language instruction bores me. & 70(16.7) & $106(25.2)$ & $107(25.2)$ & $136(32.4)$ & 2.31 & 1.517 \\
\hline 4. & I enjoy my teacher asking questions during lesson. & $283(67.4)$ & $116(27.6)$ & $12(2.9)$ & $9(2.1)$ & 3.60 & .653 \\
\hline 5. & Asking me questions when the lesson is going on distracts my attention & 72(17.1) & $66(15.7)$ & $112(26.7)$ & $170(40.5)$ & 2.10 & 1.114 \\
\hline 6. & Formative assessment is time consuming. & $122(29.0)$ & $141(33.6)$ & $84(20.0)$ & 73(17.4) & 2.79 & 1.090 \\
\hline 7. & Corrective feedback enhances my learning. & $241(57.4)$ & $124(29.5)$ & $35(8.3)$ & $20(4.8)$ & 3.40 & .832 \\
\hline 8. & I adopt a deeper approach to learning whenever I am corrected. & $228(57.4)$ & $136(32.4)$ & $34(8.1)$ & 22(5.2) & 3.36 & .841 \\
\hline 9. & I feel bad when my mistake is pointed out in the class. & $114(27.1)$ & $113(26.9)$ & $94(22.4)$ & 99(23.6) & 2.58 & 1.123 \\
\hline 10. & Corrective feedback is beneficial to my everyday learning. & $275(65.5)$ & $229(28.3)$ & $18(4.3)$ & $8(1.9)$ & 3.57 & $.668^{\circ}$ \\
\hline 11. & Corrective feedback helps me to know where I am lacking after each feedback. & $290(69.0)$ & $106(25.2)$ & 18(4.3) & $6(1.4)$ & 3.62 & .639 \\
\hline 12. & I like it when my teacher points out my mistakes & $267(63.6)$ & $119(28.3)$ & 14(3.3) & $20(4.8)$ & 3.51 & .777 \\
\hline
\end{tabular}

Weighted mean $=3.18$

From table 2, result of item 1 shows that 309 students representing $73.6 \%$ and 103 students representing $24.5 \%$ with mean of 3.71 and standard deviation of .53 agreed that formative assessment improves their performance. 260 students representing $61.9 \%$ and 150 students representing $35.7 \%$ with mean of 3.60 and standard deviation of .54 agreed that formative assessment makes them to be actively involved in learning process. 107 students representing $25.5 \%$ and 136 students representing $32.4 \%$ with mean of 2.31 and standard deviation of 1.5 disagreed that the use of formative assessment in English language instruction bores them. This, in line with the teachers' response, shows that formative assessment does not make the class boring. Consequently, 283 students representing $67.4 \%$ and 116 students representing $27.6 \%$ agreed that they enjoy their teachers asking questions during lesson. 112 students representing $26.7 \%$ and 170 students representing $40.5 \%$ with mean of 2.10 and standard deviation of 1.11 disagreed that asking them question when the lesson is going on distracts their attention. 122 students representing $29.0 \%$ and 141 students representing $33.6 \%$ with mean of 2.79 and standard deviation of 1.09 agreed that formative assessment is time consuming.

Item 7 shows that 241 students representing $57.4 \%$ and 124 students representing $54.3 \%$ and 136 students representing $32.4 \%$ with mean of 3.36 and standard deviation of .841 agreed that they adopt a deeper approach to learning whenever they are corrected. 114 students representing $27.1 \%$ and 113 students representing $26.9 \%$ with mean of 2.58 and standard deviation of 1.12 agreed that they feel bad when their mistake is pointed out in the class. 275 students representing $65.6 \%$ and 119 students representing $28.3 \%$ with mean of 3.57 and standard deviation of .67 
agreed that corrective feedback is beneficial to their everyday learning. Subsequently, 290 students representing $69.0 \%$ and 106 students representing $25.2 \%$ with mean of 3.62 and standard deviation of .639 agreed that corrective feedback helps them to know where they are lacking after each feedback while 267 students representing $63.6 \%$ and 119 students representing $28.3 \%$ with mean of 3.51 and standard deviation of .78 agreed that they like it when their teachers point out their mistakes. The overall weighted mean is 3.18. It can be concluded from this result that the students have positive attitudes to formative assessment and corrective feedback.

\section{Testing the Hypotheses}

Hypothesis 1: There is no significant difference between male and female teachers' attitude towards formative assessment and corrective feedback

Table 3: Summary of t-test statistics showing difference between attitudes of male and female teachers to formative assessment and corrective feedback

\begin{tabular}{|c|c|c|c|c|c|c|c|}
\hline School type & $\mathbf{N}$ & Mean & Std. Deviation & df & $T$ & Sig & Std. Error Mean \\
\hline Male & 4 & 35.00 & 1.414 & & 1.633 & 1.000 & 0.707 \\
\hline Female & 2 & 33.00 & 1.414 & 2 & & & \\
\hline
\end{tabular}

The above table shows that there is no significant difference between male and female teachers' attitudes towards formative assessment and corrective feedback ( $t=1.633, p>0.05$ ). Therefore, hypothesis 1 is not rejected.

Hypothesis 2: There is no significant difference between male and female students' attitudes towards formative assessment and corrective feedback.

Table 4: Summary of t-test statistics showing difference between attitudes of male and female students to formative assessment and corrective feedback

\begin{tabular}{|l|c|c|c|c|c|c|c|}
\hline Gender & N & Mean & Std. Deviation & df & T & Sig & Std. Error Mean \\
\hline Male & 218 & 37.51 & 3.732 & \multirow{2}{*}{2} & \multirow{2}{*}{-3.405} & .835 & .253 \\
\cline { 1 - 4 } & Female & 202 & 38.77 & 3.838 & & & .270 \\
\hline
\end{tabular}

The above table shows that there is no significant difference between male and female students' attitudes towards formative assessment and corrective feedback $t=-3.405, p>0.05$. Thererefore, hypothesis 2 is not rejected.

\section{Discussion of findings}

\subsection{Attitude of teachers towards formative assessment and corrective feedback in English Language instruction}

The finding of this study revealed that the teachers have moderately positive attitude towards formative assessment and corrective feedback. The finding of this study agrees with the studies carried out by Hallam, Kiston, Peffers, Robertson and Stobart (2004) and Condie, Livingstone and Seagraves (2005) who reported that head teachers and education authority coordinators were strongly convinced that the formative assessment project was highly effective. Teachers also indicated that the use of formative assessment in their classrooms had had a significant impact on pupils' self-esteem, with work and attainment. The finding however disagrees with the study carried out by (Ancker, 2000) who reported that formative assessment and corrective feedbacks had negative impact on students' confidence and motivation.

\subsection{Attitude of students towards formative assessment and corrective feedback in English Language}

Findings further revealed that students have positive attitude towards formative assessment and corrective feedback. This finding agrees with the study carried out by Peterson and Siadat (2009) which reported that the more formative feedback that students received, the better they did on final assessment. 


\subsection{Teachers' gender and attitudes to formative assessment and corrective feedback in English Language}

The results revealed that there was no significant difference in the attitudes of male and female teachers to formative assessment and corrective feedback. This finding agrees with Singh, Patel and Desai (2013) who found that there was no significant difference in the mean attitude of male and female undergraduate students towards continuous internal assessment. It also disagrees with Monday, Akon and William (2006) who reported that the attitude of female teachers towards evaluation is more positive than that of their male counterparts. It however disagrees with Monday and Akon (2004) who found that the attitudes of male teachers are more positive than the attitudes of female teachers.

\subsection{Students' gender and attitudes to formative assessment and corrective feedback in English language}

The results also revealed that there was no significant difference in the attitudes of male and female students to formative assessment and corrective feedback. This finding disagrees with that of the study carried out by Sanders, Hill, Meyer, Fyfe, Fyfe, Ziman and Koehler (2007) who reported that males are less likely to recognize the need to participate in formative assessment tasks and thus lose the benefit of on-going feedback. Ajogbeje (2014) affirmed that male attitudes to formative test with feedback are more positive than females.

\section{Conclusion}

The findings showed that teachers and students possessed favourable disposition and positive attitudes towards formative assessment and corrective feedback in English language. It can therefore be concluded from this study that formative assessment and corrective feedback are indispensable to students' learning outcome in English Language classroom. Therefore, these two variables must be made important components of English Language instruction for better result.

\section{Recommendations}

Based on the findings, the following recommendations are made:

1. Formative assessment should be given more prominence in assessing students' learning outcomes.

2. English language teachers should be exposed to seminars, conferences and workshops on how to deploy formative assessment and corrective feedback effectively in English Language classrooms for better results.

3. Teacher training programmes in colleges of education and universities should incorporate the training of preservice teachers in the use of various formative assessment strategies and how it can be used to promote learning.

\section{References}

ACELAC (Atlantic Canada English Language Art Curriculum). (2014). Assessing and evaluating students learning. Retrieved Sept. 17, 2014 from www.ed.gov.nl.ca/edu/k12/curriculum/guides/english/primary/studentaccesss.pdf.

Agbesanwa, F.O. (2014). English language teachers' awareness and utilization of assessment strategies in selected senior secondary school in Ikenne local government of Ogun state.Unpublished Masters Project. Department of Teacher Education, University of Ibadan.

Ajogbeje, O.J. (2014).Effect of formative testing on students' achievement in junior secondary school Mathematics.European Scientific Journal, 8.8

Ancker, W. (2000). Errors and corrective feedback: updated theory and classroom practice. English Teaching Forum 38: 20 - 25. Retrieved Aug. 5, 2014 from https://books.google.com.ng/books?

Black, P. and William, D. (1998). Assessment and classroom learning.assessment in education, principles, policy and practice 5.1: 7 68.

British Council. (2014). Feedback. Retrieved June 20, 2014, from (http://www.teachingenglish.org.uk/knowledge.database/feedback

Condie, R., Livingstone, K. and Seng, L. (2005). Evaluation of the assessment is for learning is for learning programme: Final report and appendices. The quality of education centre, University of Strathclyde, Retrieved from www.scotland.gov.uk/publications/ 2015/12/210792641/26428

Ellis, R., Loewen, S. and Erlam, R. (2006) .Implicit and explicit corrective feedback and the acquisition of L2 grammar studies of second language acquisition, 28, $339-368$.

Fakeye, D.O. (2011). Locus of control as a correlate of achievement in English as a second language in Ibadan.The journal of 
international social research, 4.17

Hallam, S., Kiston, A., Peffers, J., Robertson, P. and Stobart, G. (2004) .Evaluation of project 1 of the AIFL development programme: Support for professional practice in formative assessment. Institute of Education (IOE), University of London. Retrieved from www.scotland.gov.uk/publications/2004/10/19947/42988

Monday, T.J., Akon, M.J. and William, A.K. 2006. Use of student achievement scores as basis for assessing teachers' instructional effectiveness: Issues and Research Results: NationalForum of Teacher Educational Journal Volume 16, Number 3.

Nesa S. (2014). What are the advantages and disadvantages of formative assessment? Retrieved on 6th August, 2014 from everydaylife.globalpost.com/advantages-disadvantages-formativeassessment-28407.html

Siadat, M.V. (2009). Combination of formative and summative assessment instruments in elementary algebra classes: A prescription for success. Journal of Applied Research in the Community College, 16(2), 91 - 102. Retrieved from ERIC database.

Pinchok, N. and Brandt, W.C. (2009). Connecting formative assessment research to practice: An introductory guide for educators. Learning Point Associates, retrieved $4^{\text {th }}$ November, 2014 from http://www.learningpt.org/rel/events.php

Rossett, A. and Sheldon, K. (2001). Beyond the podium: delivering training and performance to a digital world. San Francisco: Jossey Bass/Pfeiffer

Sanders, K., Hill, J., Meyers, J., Fyfe, G., Fyfe, S., Ziman, M. and Koehler, N. (2007).Gender and engagement in automated online test feedback in first year human biology.In ICT: Providing Choices for Learners and Learning Proceedings. Ascilite Singapore 2007 http://www.ascilite.org.au/conferences/singapore07/procs/sanders-poster.pdf 
